\title{
Directory publishers looking over the fence
}

\author{
By Toon Lowette
}

\begin{abstract}
Report on the European Association of Directory and Database Publishers (EADP) spring conference held in Barcelona, 8-9 May 2008. This European professional organisation of yellow page and business directory publishers is increasingly becoming a database publishers organisation. Its members realize that although they still are strong at the local level, they have to evolve from paper to new electronic products in order to compete with global search engines.

Keywords: Directories, Yellow pages, Conference, Barcelona, European Association of Directory and Database Publishers, EADP.

Resumen: Reseña de la conferencia de primavera de la European Association of Directory and Database Publishers (EADP) celebrada en Barcelona, 8-9 de mayo de 2008. Esta organización profesional de editores de páginas amarillas, guías de empresas, etc., se está convirtiendo en una organización de editores de base de datos. Sus miembros se dan cuenta de que a pesar de que todavía son fuertes a nivel local con sus guias, tienen que evolucionar desde el papel a los nuevos productos electrónicos con el fin de competir con los motores de búsqueda mundiales.

Palabras clave: Directorios, Páginas amarillas, Conferencia, Barcelona, Asociación Europea de Editores de Directorios y Bases de datos, EADP.

Lowette, Toon. "Directory publishers looking over the fence". En: El profesional de la información, 2008, v. 17, n. 5, septiembre-octubre, pp. 573-574.

DOI: $10.3145 /$ epi.2008.sep.14



Toon Lowette started working in electronic publishing and interactive services in 1982. He has managed projects, launched companies, consulted the EU Commission, telecom operators, banks and other corporations, professional organisations such as the $E A D P$, published market and industry reports, etc.
\end{abstract}

ON 8 AND 9 MAY IN BARCELONA, search was again the central theme of the spring conference of the European Association of Directory and Database Publishers (EADP).

And in this conference, they specifically looked over the fence, as the conference title suggests. Yellow page and business directory publishers more and more look outside of their fields into the activities of other industries, such as classified advertising, search engines, mashups, social communities and e-commerce.

Yellow pages are about local purchase-related search, so they work more or less in the same field as the local search capacities of search engines such as Google and Yahoo!.

In the opening session, CEOs of publishing houses told the 200 participants to look over fences and collaborate with neighbours. For
Germany's DeTeMedien, Oliver Neuerbourg explained how the largest directory market in Europe is evolving into a diversified search arena. The traditional contact address content of directories has been complemented with maps, product information and point of interest information; the walled gardens between media are falling away with more co-operation between print, online and mobile services and providers.

In the CEO session, testimonies from Japan's NTT, South Africa's $T D C$ and Israel's Golden Pages indicated how their local situations regarding technology, habits and internet literacy may differ from other continents, but consumers

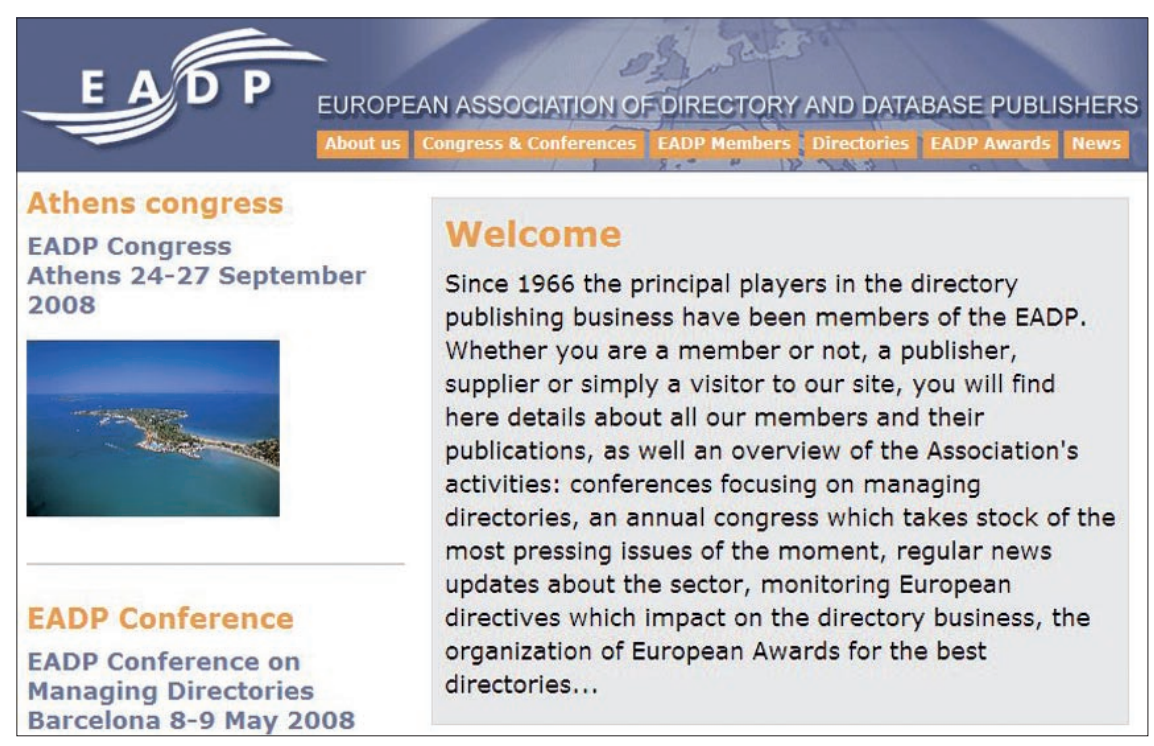

El profesional de la información, v. 17,n. 5, septiembre-octubre 2008 
looking for merchants and merchants looking for visibility are expecting the same usefulness from what the publishers offer.

\section{Publishers also involved in the campaign results}

A few remarkable over-thefence elements were touched upon in other sessions. First, these search database publishers are being challenged by e-commerce. Traditionally, they have been in the business of bringing buyers and sellers together, facilitating the contact, and that is it. The actual sale or result was not the concern of the publisher. Yet, pay-per-click and payper-result advertising has quietly brought them into the same world as the merchant who wants the best visibility-result balance. And now, why wouldn't publishers help the merchant (plumber, beauty parlour, bed-and-breakfast...) to better perform by offering an online booking and reservation system? That service is being made real by the Dutch company Libersy.

\section{Social networking}

In the next fenced garden are the social communities, such as $\mathrm{Fa}$ cebook, Myspace, Bebo and others. These communities of friends build huge profile databases, in which the members can search and find and often go to a merchant who is recommended in a group or a forum. Yme Bosma of the community Hyves learned as much about directories as he taught the audience about communities. And both sides learned that this as well is a fence to leap over.
Local search is presented in other media as well, in the wellknown old form of classified advertisements. Newspapers often carry large quantities of small adverts, as do specialised business and hobby magazines. For database publishers, search keywords in directories or classifieds look very much the same.

\section{Hands-on to compete with global players}

For a number of years, the $E A D P$ spring conference has included an interactive hands-on session in the first afternoon. This year, 10 teams with video cameras went out in Barcelona to make digital video advertisements of hairdressers, restaurants, yacht renting, ice cream shops, etc. Scripts were written, video footage edited and clips composed. The result was an amazing proof that with simple material and online video editing software, merchants can enrich their content offering in directories with living images.

Since the first spring conference in 1996, directory publishers have learned that their books are still useful and not yet entirely dead, but that the interactive services make their companies shift from advertising sales organisations into rich content database publishers, delivering their search service not just once per year, but as a permanent, mobile service, accessible anywhere anytime. Through this transition, they learn that with their local strength and with consistent database enrichment, they can be valuable local and national alterna- tives to the global search players.

\section{About EADP}

The EADP, the European professional organisation of yellow pages and business directory publishers is now increasingly becoming a database publishers organisation. Founded in 1966, EADP has its headquarters in Brussels. The principal activity of the association is to track and influence European evolution and policies concerning database protection, privacy regulation and environmental issues regarding mass book publishing, and to publish market surveys and benchmark studies. The approximately 300 members are European publishers, with a few publishers from other continents. Software and system vendors can be associate members. Every year, the member congress is held in a different European city: this year in Athens (24-27 September 2008), next year in Prague. The spring conference started in the early internet days as an electronic directories conference and now features workforce and management themes for database publishing. This conference is held in Mediterranean cities, with each city hosting a three-year cycle. The third spring conference to be held in Barcelona will be 28-29 May 2009.

\section{http://www.eadp.org}

Toon Lowette, GRID, Electronic Publishing Consultancy, Lakensestraat, 147 b 15, B-1000 Brussels

toon@grid.be

http://www.grid.be

Ven al Spanish Meeting Point, una plataforma ideal para presentar una investigación universitaria (gratuitamente) o un producto comercial en Londres: posters, power-points, distribución de folletos...

Disfruta la feria de la Online Information Conference y haz contactos desde nuestro stand n. 754, Olympia Grand Hall, 2-4 diciembre de 2008.

Escríbenos: epilondres@gmail.com

http://elprofesionaldelainformacion.com/londres

Organizado por información

